\title{
APONTAMENTOS E INDÍCIOS DO USO DA PERFORMANCE COMO REFERENTE NOS GÊNEROS TELEVISUAIS
}

\author{
INDICATIONS AND USAGE OF THE EVIDENCE CONCERNING \\ THE PERFORMANCE AS TELEVISUAL GENRES
}

\author{
INDICACIONES Y USO DE LA EVIDENCIA SOBRE EL RENDIMIENTO \\ COMO GÉNEROS TELEVISIVOS
}

\author{
Alexandre Schirmer Kieling \\ Universidade Católica de Brasília \\ alexandre.s.kieling@gmail.com
}

\begin{abstract}
Resumo
Os gêneros televisivos há muito têm apresentado um processo de diluição das suas fronteiras e de hibribidização. Com a emergente convergência de mídias a partir da digitalização dos meios, os conteúdos televisuais apresentam novas configurações. È o caso da performance que se mostra recorrente como referência dos gêneros da TV. O presente artigo resgata parte de um esforço desenvolvido na nossa tese de doutoramente no qual se buscou compreender a conformação dos conteúdos que predominam nas revistas eletrônicas. Em princípio, entendidos como jornalísticos, esses programas se mostram contaminados pela demanda do entretenimento e da audiência.
\end{abstract}

Palavras-Chave: Gêneros. Revista eletrônica. Performance.

\section{Resumen}

Los géneros televisivos siempre han presentado un proceso de dilución de sus fronteras y por supuesto de hibridación. Con la emergente convergencia de los medios de comunicación, mediante el uso de los medios digitales, los contenidos televisivos presentan una nueva configuración. Es el caso de los resultados que muestra el rendimiento performático como una referencia de los géneros televisivos. En este artículo se recoge parte de un esfuerzo en nuestra tesis de doctoramiento en el que trató de comprender la conformación de los contenidos que predominan en las revistas electrónicas. En principio, entendido como el periodismo, estos programas muestran contaminados por la demanda del entretenimiento y de la audiencia.

Palabras claves: Géneros. Revista Electrónica. Rendimiento. 


\begin{abstract}
The television genres have long presented a process of dilution of its borders and to promote hybridization. With the emerging convergence of media by using digital media, TV content present new settings. It is the case of performance that shows the applicant as a reference of TV genres. This article captures part of an effort in our doctoral thesis in which he sought to understand the conformation of the contents that are prevalent in programs fait divers. In principle understood as journalism, these programs show contaminated by demand entertainment and audience.
\end{abstract}

Keywords: Genres. Electronic Magazine. Performance.

\title{
1. OS GÊNEROS E A REALIDADE
}

O presente processo de convergência de mídias e de conteúdos, que contempla um convívio comum entre o fluxo contínuo das grades de televisão com os fluxos fluídicos, não lineares da internet, dos dispositivos de gravação ou recepção móvel, efetivamente tem movimentado as relações entre as instâncias de produção e recepção. Na nossa tese de doutoramento (KIELING, 2009) postulamos que essas dinâmicas de bidirecionalidade têm como lugar operativo uma ambiência midiática na qual se promovem as intersecções entre os sistemas fechados (produção e distribuição) e os sistemas abertos (leitura e interpretação). Nelas se dão produção, circulação e consumo. Não há como olhar o universo que se constituiu nesse espaço da midiosfera (3), como optamos por designar, sem perceber uma mudança que se opera na produção de conteúdos e na atuação dos sujeitos comunicacionais nessa ambiência.

Para perceber tais implicações, acredita-se que é pertinente pensar nos gêneros narrativos que articulam as construções que se produzem na midiosfera(4). O exemplo da televisão se mostra bastante rico. Se olharmos o caso das revistas eletrônicas essa incursão se mostra promissora. O "Fantástico", da TV Globo, é um caso. O conceito editorial se compromete em "misturar jornalismo e entretenimento(5) de maneira dinâmica e acessível"(6). Esta amplitude de referentes de realidade (mundo real e mundo da diversão), por si só, torna complexo qualquer enquadramento do programa da Rede Globo nas categorias de gêneros televisivos mais conhecidas (programas de informação, ficção e de entretenimento). Como então classificar um programa que apresenta conteúdos jornalísticos, seriados de costumes e de humor, videoclipes, jogos? 
Invariavelmente, as chamadas revistas eletrônicas promovem essa mistura de informação e entretenimento numa oscilação entre o hardnews ao softnews(7). A forma de apresentação da notícia tende a mover-se entre o relato objetivo de eventos do cotidiano que ocupam a agenda da mídia (e agenda social) e as narrativas que recorrem à criação imaginativa (MOTTA, 2006), às permissividades literárias, à metáfora, à ficcionalidade. Cada vez mais o texto seco e impessoal do relato cede espaço para o texto narrativo que incorpora personagens, tramas e dramas. Ainda que em muitos casos as histórias e personagens sejam reais, a apropriação dela ganha um volume de enredo.

Vale recordar que, como assinala Motta, as notícias, de maneira geral, lidam com o conflito e fazem isso de forma dramática, valorizando rupturas e o lado negativo. E por mais histórico que o jornalismo pretenda ser, a "notícia é sempre suscetível a interpretações sutis" (MOTTA, 2006, p. 49).

O fato é que esse espaço de manobra entre o Hard e o Soft, entre o relato e a narrativa, entre a referência de realidade e a realidade construída, faz surgir outras formas de contar histórias que transcendem essas duas esferas. O hibridismo, às vezes diluído, do qual se constitui um programa como o "Fantástico", dificulta o aporte de uma taxonomia pertinente.

Nem mesmo o âmbito classificatório das notícias chamadas fantásticas, que incluem tudo que foge do comum, do cotidiano, seja o curioso, seja o bizarro, seja o grotesco, é suficiente para dar conta da gama de combinações de conteúdos produzidos e veiculados nesses programas. Nem mesmo a ideia de "revista eletrônica" resiste suficiente para designar a amplitude temática e as diversidades de textos distribuídos ao longo dos blocos exibidos durante mais de duas horas nos domingos à noite seja na Rede Globo, seja na Rede Record. Essa perspectiva nos desafia a compreender o movimento fronteiriço dos gêneros na TV.

Com efeito, diversos autores (Blanchot, Barthes e Derrida, para citar alguns) já sinalizaram, tem tempo, o quanto as fronteiras entre os gêneros tradicionais (no caso, literários) se diluem e misturam. Arlindo Machado, um dos principais pesquisadores brasileiros a enfrentar tal questão do gênero televisual, considera que, de maneira geral, os gêneros são categorias mutáveis e heterogêneas, "não apenas no sentido de que são diferentes entre si, mas também no sentido de que cada enunciado pode estar replicando muitos gêneros ao mesmo tempo" (MACHADO, 1997, p. 71). 
O conceito de gênero (que apresenta classificações peculiares a cada mídia de expressão - cinema, rádio, TV), por certo, dificulta ainda mais qualquer classificação quando aplicado especificamente à televisão, uma vez que parte da premissa da estabilidade, da regularidade(8). Paolo Fabbri vai afirmar que o gênero seria "a unidade mínima do conteúdo da comunicação de massa" (FABRI apud in MARTIN-BARBERO, 1997, p. 298). E isso não se aplicaria apenas à ficção, uma vez que a demanda por produtos tanto do mercado como do meio e do público se faz no nível do gênero.

Para os investigadores, é através da percepção do gênero que se alcança o sentido latente dos textos dos mass média. A dinâmica cultural da televisão atua pelos seus gêneros, que ativam a competência cultural e, a seu modo, dão conta das diferenças sociais que atravessam. Os gêneros, que articulam narrativamente as serialidades, constituem uma mediação fundamental entre as lógicas do sistema produtivo e as do sistema de consumo, entre a do formato e as formas de ler, de uso (MARTIN-BARBERO, 1997, p. 298-299)

Além de Martin-Barbero reflexão sobre os gêneros televisivos tem ocupado diversos autores, todavia no presente texto nossa opção será tensionar uma perspectiva em particular. Trata-se de um postulado que associa a dinâmica dos gêneros com o processo comunicacional na TV. Uma visada com base na semiótica pragmática articulada pelo semiólogo francês François Jost para quem "todo o gênero é fundando sobre a relação com um mundo cujo grau de existência condiciona a adesão ou a participação do telespectador” (p 27, 2004). Portanto, uma dinâmica cuja aplicação se aproxima da nossa proposição de ambiência midiática gerada pela intersecção dos sistemas aberto e fechado de produção de conteúdo e geração de sentido.

Jost vai nos dizer que o gênero opera como uma interface que, por sua vez, seria responsável "pela ligação entre emissor e receptor" (JOST, 2004), ou seja, entre a televisão e o telespectador. Admitindo ainda que um gênero carregue em si uma estratégia de comunicabilidade tal como pensaram Casseti e Wolf e foram endossados por Martin-Barbero (1997) e Duarte (2004), teríamos uma categoria sígnica essencial para a comunicação midiática. Suas indicialidades e referencialidades são pistas indissociáveis da produção e compreensão textual. Nesse sentido, Jost diz que o gênero "é uma moeda de troca que regula a circulação dos textos ou dos programas audiovisuais no mundo midiático" (JOST, 2004, p. 27). 


\section{O GÊNERO COMO PROMESSA}

Considerando que os gêneros contêm uma promessa ontológica ou constitutiva (que diz respeito ao pertencimento) como o exemplo de que uma comédia deve fazer rir ou que, nos programas de emissões ao vivo, existe uma promessa de autenticidade maior do que em outros tipos de programas, Jost postula o conceito de promessa pragmática como constitutivo do gênero. A indicação de 'vivo' na tela, por exemplo, seria uma promessa ontológica por naturalmente passar a idéia de transmissão em tempo real. Já o locutor, dizendo que fala ao vivo, informando, logo a seguir, a hora e chamando um repórter com o qual conversa durante a transmissão, seria uma promessa pragmática. Isso faria com que as emissoras, para influenciar crença, antecipariam uma denominação ou classificação do gênero. Este funcionaria como referência exercendo uma ação sobre o telespectador. Essa referencialidade, por sua vez, estaria fundada na relação "com um mundo cujo grau de exigência condiciona a adesão ou participação do telespectador" (JOST, 2004, p. 27).

Nesse sentido, além do programa (do texto em si), os produtos televisuais são acompanhados hoje em dia por uma multiplicidade de divulgação. São ações anteriores às exibições, que se estendem ao longo das exibições, especialmente no caso das seriadas. Peritextos, paratextos e epitextos "são promessas sobre o benefício do prazer simbólico que o telespectador vai usufruir" (JOST, 2004, p. 27). Assim, segundo Jost, a promessa se funda em três proposições:

a) o gênero é uma moeda de troca que regula a circulação dos textos ou dos programas audiovisuais no mundo midiático;

b) o texto ou o programa é um objeto semiótico complexo (deixando de lado a questão se o programa pode verdadeiramente ser considerado um texto);

c) disso resulta que o gênero é uma construção por exemplificação de algumas amostras de propriedades que o texto possui entre outras. Uma novela pode ser percebida tanto como ficção, como também uma peça que trata dos documentos da tela, um documento sobre a realidade. No contexto televisual, a emissora é a instância, se assim se pode chamar, onomaturgia, que decide ou propõe a generalidade do produto. Enquanto ato promissivo esse quase batismo (trata-se de batizar cada programa) tem o estatuto de um ato unilateral (JOST, 2004, p. 27-28).

Todavia, o que aparentemente se mostra unilateral, na verdade propõe um engajamento em relação à promessa, ou seja, é conferido ao receptor o direito correlativo de exigir que a promessa seja cumprida. Haveria, dessa maneira, uma assimetria, já que a 
promessa só se atualiza na confiança mútua. Implica reciprocidade. Jost esclarece que o ato promissivo do gênero é duplo, indicando uma ramificação em duas promessas:

a) a promessa constitutiva do gênero, que forja o horizonte de expectativa do qual o gênero é portador: da mesma forma como o belo é uma promessa de felicidade, a comédia é uma promessa de riso. Essa promessa que engendra crenças é também feita de saberes mais ou menos partilhados (JOST, 2004, p. 29).

b) a promessa pragmática - saber aquilo que ficção ou direto (ao vivo) quer dizer; não coloca ninguém ao abrigo dos erros de interpretação, ou dos desvios em relação às marcas do emissor. Se certos textos ou programas são imediatamente identificáveis - como romance, filme de ficção ou jogo - numerosos objetos midiáticos hoje operam com ambigüidade. Permitem influir na interpretação espectatorial pela categorização (JOST, 2004, p. 30).

Aqui, talvez, a contribuição mais rica do postulado de Jost. Para que se consume a promessa pragmática do engajamento, entram em ação as motivações do telespectador. $\mathrm{Na}$ escolha do nome de um programa, por exemplo, o engajamento vai se dar a partir do interesse e das emoções daquele que vai procurar ver o produto anunciado. Ou ainda o engajamento vai averiguar os níveis de garantia que assegurem encontrar no programa os atributos exemplificados nas amostras, que são os anúncios, as chamadas, a autopromoção nas mídias. Embora trate particularmente das estratégias de comunicação e relacionamento das emissoras com os telespectadores, uma característica muito forte das emissoras na França é a valorização dos seus portais, sites, cadastros de telespectadores. Destaque-se a percepção da existência de um espaço de construção simbólica no qual emissor e receptor atuam. É nessa dinâmica que Jost encontra o terreno comum no qual emissoras, programadores, mediadores e telespectadores se comunicam. Trata-se de um espaço constituído pelos mundos da televisão, que confere sentido aos gêneros de televisão, ou talvez uma noção de macro gêneros.

\section{O GÊNERO E OS MUNDOS DA TV}

Nunca é demais lembrar a primeira edição de reality show como o Big Brothers Brasil, quando houve um estranhamento dos telespectadores sobre a categoria, a natureza do programa. Era realidade? Era ficção? Houve um período de adaptação da promessa inicial de um programa da vida em tempo real para a compreensão (adesão do telespectador) como um 
programa de jogo interativo que envolveu mais de 50 milhões de votos de telespectadores no processo de exclusão de um candidato, como verificada na edição 2009 (9. ${ }^{a}$ versão do programa). Jost destaca que um caso semelhante aconteceu na França, e o programa terminou por ser classificado como tele-realidade.

Agora, para que esse processo da adesão ou participação do receptor se consume, implicaria que "todo o gênero repousa na promessa de uma relação como o mundo cujo modo ou grau de existência condiciona" (JOST, 2004, p. 33) a adesão do telespectador. Equivale dizer que se faz necessária uma referencialidade. Um documento (audiovisual ou não), por exemplo, é produzido em função de um tipo de crença visada pelo destinador, todavia só poderia ser interpretado por quem possui uma ideia anterior de vínculo com a realidade. Em outras palavras, na TV, as imagens necessariamente precisariam remeter a objetos existentes ou ficcionais. Como lembra Jost, a informação é sempre submetida ao exercício de prova. Pensando-se no exemplo dos telejornais, documentários e transmissões ao vivo, promove-se a "impressão de testemunhas do mundo". Evidencia-se, novamente, que a transmissão ao vivo confere autenticidade.

Nesse sentido, como as imagens, ou remetem ao mundo natural ou representam um mundo parecido com o nosso, o gênero tende a fixar o grau de existência do mundo que for apresentado pelos programas ao espectador (leitor). Tal perspectiva remeteria aos mundos referentes da TV, ao real e ao ficcional. Mas, como visto até aqui, os programas televisuais, atualmente, superam a fronteira desses dois referentes. Para superar essa dificuldade, Jost vai acrescentar aos mundos real e ficcional o mundo lúdico que, por sua vez, daria conta dos programas de entretenimento que apresentam todo tipo de jogos. São esses mudos que viriam a configurar as promessas de gêneros do real, ficcional e lúdico que o autor propõe.

Assim, ao lado do verdadeiro, da informação que toma o mundo natural como referente (telejornais, documentários, talk shows, debates), do falso da ficção que o referencia no universo mental (séries, seriados, telefilmes, telenovelas, sitcoms), "é preciso acrescentar um para rir no qual a mediação se toma como objeto, quer se trate de jogar com a linguagem, de jogar com o jogo ou de fazer arte pela arte" (JOST, 2004, p. 40). Esse mundo referente, denominado assim de lúdico, abrigaria especialmente as variações de reality shows, como "No Limite", "Jogo Duro", "Fama" (da TV Globo), "Show dos artistas", "Show do milhão" (SBT), entre outros. 
3.1. A migração entre os mundos, relatos e narrativas

Resgatemos o triângulo proposto por Jost (figura 1) por intermédio do qual situa os três mundos que referenciam os gêneros e que ajuda na compreensão do seu postulado do gênero como promessa.

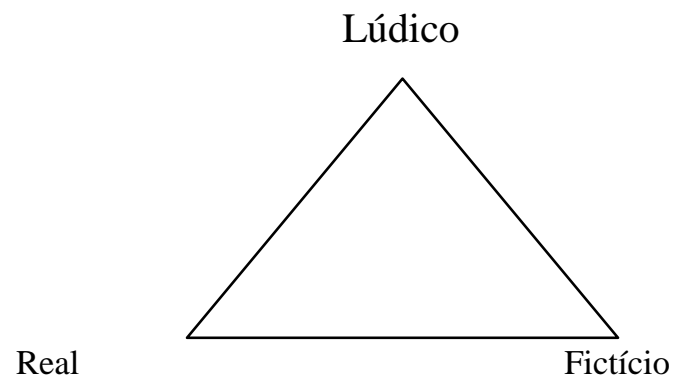

Figura 1 - Triângulo dos mundos referentes dos gêneros por Jost.

Um detalhe importante para Jost é deixar a figura em branco, uma vez que, no entendimento dele, todas as variações, migrações e hibridismos possíveis se movimentariam entre esses referentes. Seria o caso de Reality Show como o BBB (Big Brothers Brasil, da TV Globo) e a "Fazenda" (uma versão da Rede Record para o mesmo tipo de programa, que confina pessoas num local cenográfico durante meses, período no qual os candidatos são submetidos a provas e sujeitos a eliminação semanal, segundo escolha do público, por meio de votação por Internet e por telefone). Embora Jost não faça uma menção direta a esse espaço de movimento a partir do referente do mundo real, estão, acreditamos, os programas de revista eletrônica como - e especialmente - o "Fantástico", da TV Globo.

Um aspecto que se deve destacar da postulação de Jost é que a constituição do movimento do gênero no espectro da sua formulação vai estar vinculada à promessa do produtor, programador e difusor e na forma como o telespectador vai aderir à promessa a partir do seu referente de leitura e compreensão.

No momento da comunicação midiática, é difícil atribuir aos sentidos de um texto uma única interpretação. As utilizações são várias e cada um tira prazer a sua maneira do produto cultural. Essas migrações dos receptores nos gêneros, as estratégias de comunicação ou os próprios produtos operam todos no mesmo terreno. Tanto os atores da comunicação como os textos migram no espaço circunscrito por esses três mundos descritos (JOST, 2004, p. 41-42). 
O autor sugere ainda que os agentes sociais dessa esfera midiática (emissoras, programadores, mediadores como telespectadores) se situam sobre "um terreno comum" gerado pelos mundos da TV e que conferem sentido aos gêneros.

Aplicando-se essa perspectiva à configuração da midiosfera, numa dinâmica permanente, que opera esses mundos em deslocamentos dos referentes entre real, ficcional e o próprio lúdico proposto por Jost, encontramos ainda um âmbito virtual. Um processo distintivo que alarga as fronteiras para entendimento entre instâncias de produção e recepção quanto a novos formatos, especialmente se criados pela TV numa ambiência de convergência e multiplataforma. Essa virtualidade que mistura TV, Internet e telefonia móvel (SMS) permite não apenas uma migração mais fluída dos referentes nas narrativas de um programa como ajuda na agilidade de atualização da promessa de gênero.

Nesse sentido, a noção de promessa tende a ganhar força. Se pensarmos que essas instâncias estão sujeitas aos sistemas tecnológicos de produção e distribuição, estaremos pensando em sistemas fechados. Seria possível inferir que as estratégias da promessa de gênero estariam sujeitas às lógicas de regularidade desses sistemas. De certa forma, no âmbito das ações pré-exibição, sua tendência é buscar, na promessa, instrumentos que assegurem níveis de estabilidade na compreensão da narrativa. Na medida em que essa promessa é compartilhada pelo telespectador, os referentes sígnicos, a própria leitura e compreensão operam na lógica dos sistemas abertos, sujeitas às dissipações e variações da pretensão de origem, mas a ela sempre vinculada pelas atualizações interativas entre produção e recepção.

Assim, entende-se que o processo de adesão à promessa pode induzir o movimento na configuração atualizada do gênero. Nesse sentido, a revista eletrônica, no caso específico do "Fantástico", configura, a partir das formulações de Jost, um gênero específico cujo principal referente é o mundo natural, o real, mas, pelas metas de entretenimento, movimenta-se para referentes do mundo mental da ficção e também incorpora referentes lúdicos que estimulam a participação do telespectador.

Dessa maneira, poder-se-ia sugerir que a revista eletrônica, no caso muito particular do "Fantástico" (um permanente camaleão na luta por audiência), situar-se-ia no meio do triângulo de Jost. Seus movimentos da direção do real (jornalístico), ficcional (esquetes de sitcom) e, mesmo, lúdico (participação) estariam abrigados na promessa de informação e entretenimento e livremente sujeitos à adesão e à demanda dos telespectadores. A 
irregularidade desses movimentos, não apenas no exemplo do "Fantástico", nos leva a acreditar em outra ordem de referente que seja transversal aos demais e com livre movimento, uma natureza que não perderia seus referentes de origem, no caso do real de um programa informativo, mas sem as amarras canônicas do telejornal. Trata-se do performático.

Performance aqui entendida como um conceito em elaboração. Debray quando estrutura as características da videosfera apresenta a ideia de performático do ponto de vista da máquina como referente crucial. Se pensarmos a instituição midiática, ou a empresa midiática e suja estrutura produtiva no âmbito de um sistema fechado, o sentido de performance vai aparecer como desempenho desse sistema. O que se propõe é a priori é sim a ideia de desempenho, mas como uma interface entre a migração pelos mundos de Jost e o telespectador. Performance operaria como um referente subsidiário, de apoio aos três referentes real, ficcional e lúdico. Funcionaria como um constructo, um indutor e/ou articulador do movimento entre os mundos referentes.

Se considerarmos que, na esfera do processo que apresenta a promessa de gênero pela emissora, ela recorre a todas as mídias disponíveis na busca do telespectador e igualmente lança mão dos mesmos dispositivos midiáticos para exibição e participação do receptor, o gênero tende a também se configurar no espaço da ambiência midiática, portanto opera na dinâmica da midiosfera com base na performance. Na capacidade dos agentes comunicacionais se deslocarem, a partir de uma história base dos referentes do mundo real, para o ficcional ou para o lúdico.

\subsection{Um exemplo}

Para melhor compreensão desta dinâmica, vamos tomar como exemplo a abordagem que o Fantástico costuma fazer no tratamento de temas que envolvem outros programas exibidos na mesma emissora e de grande repercussão pública, como o caso das telenovelas, ou seja, uma narrativa de ficção é tratada jornalisticamente como um produto cultural de destaque.

Na edição do dia 19 de agosto de 2007, o programa fez uma reportagem com a atriz Alessandra Negrini sobre a dificuldade de se interpretar quatro personagens em uma mesma telenovela. Alessandra representava o papel de duas personagens que eram irmãs gêmeas na trama e que, num jogo dramático adotado pelos roteiristas, no interior da narrativa, 
eventualmente uma personagem se faz passar pela outra - uma articulação que exigiria da atriz um esforço de interpretação peculiar. O tema, que é abordado numa reportagementrevista com Alessandra, que dura quase cinco minutos, inspira a produção do programa. Esta convida os telespectadores para que façam vídeos nos quais mostrem seus talentos, interpretando uma ou outra personagem (Taís ou Paula) e os postem no site do programa por meio do espaço "VC no Fantástico" (imagem 1).

Enquanto a abordagem do tema serve aos propósitos de reforçar a promessa do gênero ficcional, como defende Jost, o convite em si carrega a promessa do próprio "Fantástico" numa atualização dos movimentos específicos que faz em relação a este quadro no triângulo dos gêneros. Equivaleria a dizer para o telespectador: "neste quadro estamos te convidando para sair do mundo real (documental, da reportagem) e nos acompanhar ao mundo lúdico. Vamos brincar, vamos nos divertir juntos. Antes você precisa passar pelo mundo ficcional e produzir um vídeo em que você será o ator ou atriz". Ao mesmo tempo, há a promessa subsidiária da interatividade, da participação do telespectador, que ajudará a fazer a próxima edição.

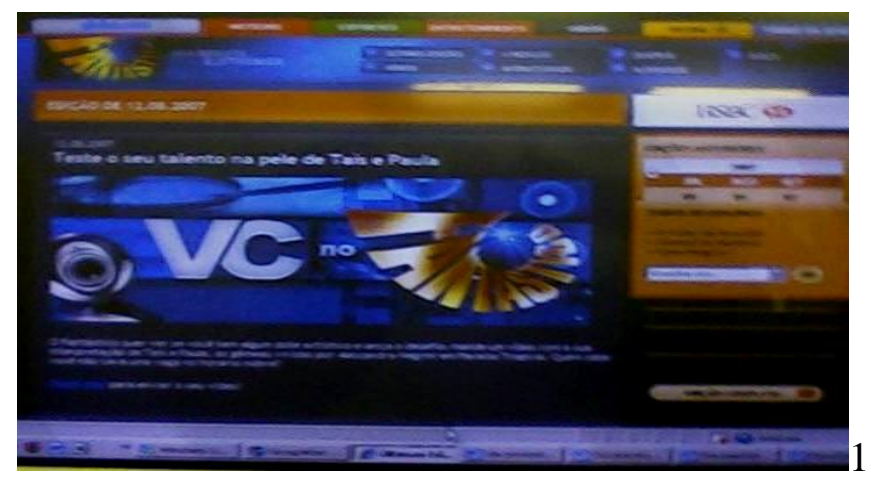

Imagem 1 - Mostra o site do "Fantástico". Aqui a convocação "teste o seu talento na pele de Taís e Paula", a produção faz referência à reportagem com Alessandra, reenviando uma mídia a outra mídia e internautas e telespectadores a um mesmo papel.

O telespectador passa, então, para a fase de conferir a promessa. Aceita participar da brincadeira para ver se efetivamente haverá a publicação. O resultado mostra mais de vinte contribuições publicadas (imagem 2). Quatro efetivamente são selecionadas e exibidas no programa, que passa a incorporar esse quadro, "VC no Fantástico", às suas rotinas de produção. As imitações dos papéis das irmãs gêmeas Paula e Taís aparecem na tela grande, 
antecedidas por uma vinheta e embaladas por um gráfico que imite a janela do software de exibição de vídeo na Web. Constitui uma nova lógica, que se materializa no âmbito da midiosfera, que é a convergência de mídias com a incorporação do discurso de reenvio de uma a outra (TV, Web e telefone), não só pela prática de produção, transmissão e exibição, mas também produção simbólica que resulta desta estratégia.

As outras contribuições que não foram publicadas ficam no site, à disposição do público que, ao acessá-lo, poderá assisti-las pela Web, juntamente com aquelas que apareceram no programa. Destaque-se que as contribuições (a maior parte de crianças e jovens, gerações mais acostumadas a novas tecnologias) superam as expectativas; algumas sugerem mudanças na trama (imagem 3).

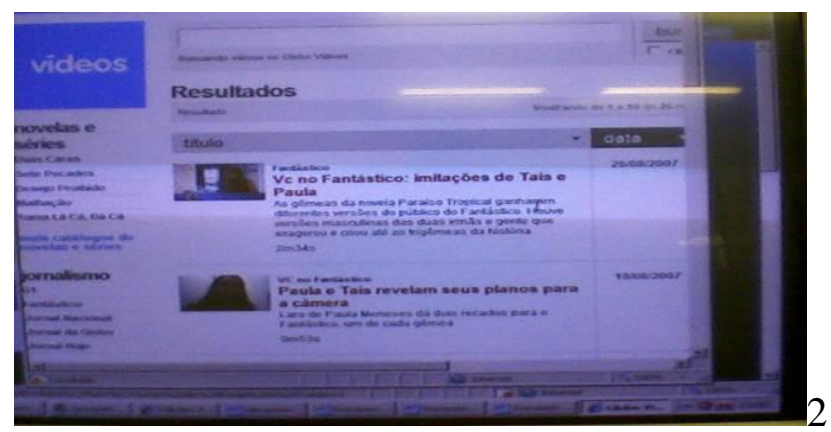

Imagem 2 - Mostra que a maioria das contribuições foi apresentada por jovens e até crianças, uma geração mais acostumada com a tecnologia, portanto ao uso de ferramentas interativas. Raros são os casos de contribuições de telespectadores/internautas com mais de 30 anos.

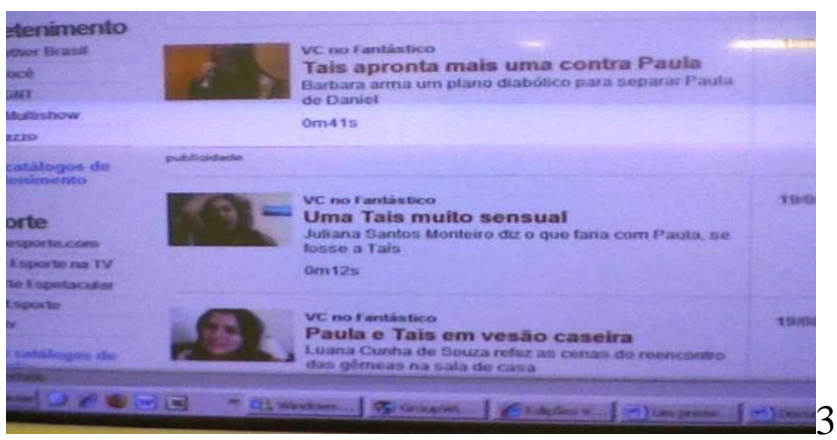

Imagem 3 - Mostra que alguns internautas/telespectadores vão além da proposta de simples imitação e criam situações novas ou paralelas à trama das oito.

A adesão do telespectador, não somente no sentido de compreensão da proposta do programa, mas de participação, fez com que as equipes de produção promovessem várias 
outras experiências de atualização da promessa com a mesma e com outras novelas nas edições seguintes.

\section{CONSIDERAÇÕES E APONTAMENTOS}

O importante, nesse movimento dos gêneros, especialmente entre os mundos televisivos descritos por Jost, é que a circunstância narrativa definida como fingimento ( o faz de conta) vai ser apresentada como promessa pelos realizadores e exibidores e que precisa contar com a adesão do telespectador. A partir daí, diferentemente de Jost, acreditamos que se segue um regime de contrato bilateral entre as duas instâncias, sujeito a atualizações mediante novas promessas e novas adesões. É essa perspectiva que nos permite compreender a fidelização de um telespectador com a telenovela que fica no ar durante três meses.

Mas não há outro programa de informação na TV brasileira que promova com tanta intensidade essas permanentes atualizações de promessa e adesão como o "Fantástico": uma capacidade de ousar, recuar, propor novamente e até radicalizar, saindo de um extremo ao outro da pirâmide de Jost (como já demonstrado), o que talvez justifique sua permanência no ar há tanto tempo (embora atualmente enfrente uma diluição de audiência com outras atrações do horário).

Além das inovações já descritas no presente trabalho, da interatividade e das atrações de entretenimento, há no jornalismo do programa a valorização pelas grandes reportagens de investigação. No caso Isabella Nardela (um pai e a segunda mulher mataram a filha do primeiro casamento dele, jogando a criança através de uma janela de um prédio classe média, em São Paulo, 2008), quando a cobertura de todos os veículos, inclusive de outros informativos da emissora, abordava a crueldade do crime (e a maior parte da mídia brasileira já condenava sumariamente o casal), o "Fantástico" foi a primeira emissora a dar voz aos acusados. Com isso, produziu um efeito de humanização e de equilíbrio na cobertura. Para o telespectador, já cansado do maçante volume de informação de origem oficial, o movimento das equipes de produção do programa renovou a promessa do mundo real e obteve uma adesão significativa da audiência.

No caso do jornalismo televisivo, propriamente, podemos observar que este se constitui a partir de uma matriz de relato que opera com recorrentes regularidades narrativas 
que apresentam pequenas, quase invisíveis, variações de uma reportagem para outra, do telejornal de um país para outro. A função do repórter narrador é a mesma: das fontespersonagem ou fontes-testemunho é igual. Da herança do referencial jornalístico do hardnews resta a assinatura do repórter falando diretamente para a câmera, assegurando a noção de credibilidade e legitimação. É exatamente esta interrelação dos meios, enquanto empresas prestadoras de serviço, e a sociedade, que vai introduzir a mídia nas regras do sistema de mercado, que, por sua vez, alimentaria esta interdependência com base nas lógicas econômicas, tecnológicas e políticas.

Retornemos, entretanto, às perspectivas da notícia hardnews e softnews. No âmbito do programa "Fantástico" podemos entender que temos a mistura do relato e da narrativa. O real e a realidade construída se atravessam; seus referentes são invertidos, se diluem e reconfiguram ao sabor da proposta de cada quadro, à luz de uma liberdade criativa de formatos e estruturas enunciativas-discursivas. Seu conteúdo não colhe material noticiável, apenas nos eventos do mundo real, mas também nos eventos criados (mundo ficcional) no âmbito das "sacadas" da redação do programa: um processo regido por uma lógica de jogo (mundo lúdico) informativo com o apoio do telespectador em narrativas articuladas pelo referente da performance, a capacidade de fazer de maneira descolada.

$\mathrm{Na}$ tendência observada nos exemplos acima a performance serve num processo de adesão e até cumplicidade do público do programa que aceita falar da realidade, suspender o real e brincar, fazer de conta. Constitui um fenômeno que vai na direção da perspectiva de campo jornalístico, tal qual imaginou Bourdieu (1996), no qual a sujeição seria aos vereditos do mercado, por meio da sanção direta da clientela e indireta dos índices de audiência, mas que recorre ao desejo pelo entretenimento para fazer uma espécie de aliança com a audiência.

E no bojo do Fast-Food cultural, descrito pelo sociólogo francês, emerge outra maneira de formatar a apresentação da notícia, de contar histórias em programa de informação na TV. Na experiência verificada no "Fantástico", teremos uma espécie do que poderíamos chamar de mixnews, um pouco de informação, um pouco de show, um pouco de relato, um pouco de narrativa, um pouco de tempo real, um pouco de tempo controlado pelo enredo, um pouco de temas da atualidade e um pouco de temas criados pela realidade paralela da TV. Tudo, porém, vem embalado por uma estética comum: a da performance. 
No mixnews, que não excluiu o hardnews e o softnews, há espaço para a participação, a colaboração do telespectador e a atuação das instâncias de produção e recepção, num jogo cúmplice de produção de conteúdo e sentido. Assim, a principal característica do mixnews é dar um tratamento performático a qualquer informação veiculada nas reportagens dos programas ditos "revistas eletrônicas". Independente de serem informações jornalísticas de assuntos que foram notícia na semana ou histórias de comportamento, de lançamentos culturais e ainda da vida e pensamentos de celebridades, a narrativa, o enredo, a montagem ou o desempenho do narrador ou do repórter vai privilegiar a performance. Essa tendência vai se manifestar nos textos mais leves, poéticos, cômicos ou dramáticos ou ainda nas trilhas, nos ruídos, sobe sons e tempo de corte na sequências de imagens apresentadas na montagem. Será que voltamos aos tempos da Vaudeville? Uma questão ainda para seguir nessa reflexão.

\section{Notas}

3 A ideia de esfera que Lotman(1993) empresta do biogeoquímico russo-ucraniano Vladimir Vernadski (1920), para quem tudo que é vivo, existe em conexão no globo terrestre, constituindo uma biosfera no interior da qual tudo em relação se opera. Para o autor, nenhum ser existe fora de um ambiente com o qual e por meio do qual atua e interage. O mesmo Vernadski também cunhou a noção de noosfera que distende esta mesma dinâmica para o âmbito do pensamento, das ideias. Uma esfera onde a reflexão e as formulações que deste resultam obedeceria à mesma dinâmica de atuação e inter-relação com o meio e suas circunstâncias. Essa perspectiva ainda foi retrabalhada pelo filósofo jesuíta francês Teilhard de Chardin (1981), que incorpora a tecnologia ou os processos tecnológicos à dimensão da noosfera (esfera na qual se estruturariam e operariam os sistemas da cultura e os sistemas mentais).

${ }^{4}$ Apropriamo-nos ainda de parte da mesma essência que, talvez, tenha inspirado Debray (1993) para fazer uma leitura das representações de poder no seu estudo do "Estado sedutor" e superdimensionar as dissipações deste processo virtual simbólico para constituir sua noção de "videosfera" na qual estruturas regidas pelo sistema econômico (mercado), em comum acordo com os sistemas de comunicação social, operam uma lógica de consenso, promovendo uma democracia de opinião por meio das sondagens. A videosfera de Debray, é a esfera na qual o ideal típico é a democracia, a tecnológica é um símbolo funcional, o monitor de TV é o lugar de exaltação, as transmissões (ao vivo) são o ritual de apresentação (visibilidade) e o status de governança estariam nas mãos do telespectador. É verdade que Debray encaminha sua postulação com um enquadramento mais na linha dos sistemas fechados, com um viés determinista acompanhando a mesma direção de Luhmann. Todavia, Debray concebe um espaço virtual através do qual as dinâmicas dos sistemas de função (inclusive o midiático) são mediadas pela mídia vídeo. Assim, o que vai nos importar aqui é a ideia de um lugar virtual de construção de sentido, em que a mediação se dá por meio dos sistemas midiáticos. Além disso, a midiasfera de Debray (1994) trata de uma linha histórica - as três idades do olhar, como diz (DEBRAY,1994, p. 203). Logosfera corresponde a idade do ídolos (sentido dos gregos). Este período estende-se até a invenção da escrita à imprensa. A grafosfera é era da arte. Época que se estende da imprensa a TV à cores. Videosfera é a era do Visual (conforme termo proposto Serge Daney).[p.206].

5 A oferta de produtos culturais destinados ao entretenimento ganhou força na sociedade liberal americana durante a primeira metade do século XX. Especialmente na década de 30, Neil Gabler (Vida, o filme, Companhia das Letras, São Paulo, 1999) registra a configuração de uma consciência devota ao prazer, à felicidade, ao esporte, à alegria. Nesse período, a imprensa americana migra para a notícia como entretenimento, uma demanda da nova face que assume o mercado de consumo da informação. Surge o Softnews com notícias brandas (MOTTA, 2006) em contraposição ao Hardnews das notícias mais duras.

${ }^{6}$ Não podemos esquecer que o Fantástico tem como slogan "O Show da vida".

\section{ANIMUS


${ }^{7}$ Como lembra Luiz Gonzaga Motta (2006), o hardnews caracteriza-se como uma obra de significação mais aberta, privilegiando o discurso descritivo "temporalmente estático", que procuraria produzir um efeito de realidade por meio do volume de informações que gerariam a verossimilhança. Ao seu turno, o softnews (mais fechado enquanto obra), embora também descritivo, tende a operar uma dinâmica narrativa que diluiu os efeitos de real e se estrutura a partir de um enredo. Essa forma de contar, de processar a notícia (também chamada de features, pelos americanos, ou fait divers, pelos franceses) se ocuparia de notícias leves sobre temas humanos, tragédias pessoais ou coletivas, animais, lugares, celebridades e comportamento.

${ }^{8}$ Considere-se aqui o entendimento de Bakthin (cuja aplicação sempre se referenciou na literatura), de que o gênero seria "uma força aglutinadora e estabilizadora" operando dentro de determinada linguagem. Seria um modo de organizar as ideias, meios e recursos expressivos, suficientemente estratificados numa cultura, de modo a garantir a comunicabilidade dos produtos e a continuidade dessa forma junto às comunidades futuras (BAKTHIN, 1967).

\section{Referências}

BAKHTIN, M. Problemas da poética de Dostoiévski. 2. ed. Rio de Janeiro: Forense Universitária, 1997b.

BOURDIEU, Pierre. Sobre a televisão. Rio de Janeiro: Zahar, 1997.

A economia dos bens simbólicos. In: Razões práticas sobre a teoria da ação. São Paulo: Papiros, 1996. p. 157 a 197.

DUARTE, Elizabeth Bastos. Televisão: ensaios metodológicos. Porto Alegre: Sulina, 2004

HJELMSLEV, L. Prolegômenos a uma teoria da linguagem. São Paulo: Perspectiva, 1975.

JIMÉNEZ, Jesús Garcia. Narrativa Audiovisual. Madrid: Cátedra, 1996

JOST, François, Seis lições sobre televisão. Porto Alegre: Sulina, 2004.

LOTMAN,I. Acerca de la semiosfera (trad. D. Navarro), Critérios, 1993:133-150.

KIELING, A.S.. Televisão: a presença do telespectador na configuração discursiva da interatividade no programa "Fantástico". São Leopoldo, tese de doutorado na Unisinos, 2009.

MACHADO, A. A televisão levada a sério. São Paulo: SENAC, 2000.

MARTIM-BARBERO. Dos meios às mediações: comunicação, cultura e hegemonia. Rio de Janeiro. UFRJ, 1997.

MOTTA, Luiz Gonzaga. Notícias do Fantástico. São Leopoldo: Ed. Unisinos, 2006. 
Original recebido em: 30/10/2012

Aceito para publicação em: 03/12/2012

Resumo sobre o autor

Alexandre Schirmer Kieling possui graduação em Comunicação Social pela Universidade Federal de Santa Maria (1985), especialização em cinema e TV (2000) mestrado (2004) e doutorado (2009) em Ciências da Comunicação pela Universidade do Vale do Rio dos Sinos. Desenvolveu uma pesquisa sobre interatividade na TV, tendo feito estágio na Sorbonne Nouvelle Paris 3 , na França. É professor do Programa de Mestrado em Comunicação e da Graduação em Comunicação da Universidade Católica de Brasília. Tem experiência em produção e gestão de realização audiovisual, especialmente em televisão. Atua e pesquisa com ênfase nos seguintes temas: digitalização das mídias, TV digital, televisão brasileira, interatividade. 